\title{
Pengaruh Model Pembelajaran Tipe Artikulasi dan Team Games Tournament Terhadap Kemampuan Representasi Matematis
}

\author{
Eugenia Wajo $^{1)}$, Era Dewi Kartika ${ }^{2)}$ \\ ${ }^{1,2)}$ IKIP Budi Utomo Malang \\ Email: ferrajenny.24@gmail.com, erfolgera@gmail.com
}

\begin{abstract}
Learning mathematics at Baleriwu Danga High School is still dominated by conventional learning. Students are always positioned as objects and are considered not to know or don't know, while the teacher positions themselves as sources that have knowledge. Based on observations it is known that students mathematics learning outcomes on LTVES material tend to be lower. Similarly, the representation ability of students in schools is still low. This can be seen from the answers of students in working on the problems. Students are less able to translate a problem into a mathematical model or vice versa. This study aims to determine the effect of the use of the Articulaion learning model and Team Games Tournament (TGT) on the mathematical representation ability of X grade students of SMAK Baleriwu Danga on the subject of the Linear Two Variable Equation System (LTVES). The method used in this research is the experimental method. The class taking in this study is the "Randomized Posttest-Only Control Design" is three group, each randomly selected and then given a final test on all three gropus. Where X IPA 1 and IPA 2 grade as an experimental class and X IPS 1 grade as a control class. The result of the research conducted were the percentage of mathematical representation ability of students in the Articulation class at $81,75 \%$, TGT class at $66,09 \%$ and the control class at $62,84 \%$.
\end{abstract} Keywords : Mathematical Representation Ability, Articulation, TGT

\begin{abstract}
ABSTRAK
Pembelajaran matematika di SMAK Baleriwu Danga masih didominasi oleh pembelajaran konvensional. Siswa selalu diposisikan sebagai obyek dan dianggap tidak tahu atau belum mengetahui, sementara guru memposisikan diri sebagai sumber yang mempunyai pengetahuan. Berdasarkan hasil observasi diketahui bahwa hasil belajar matematika siswa pada materi SPLDV lebih cenderung rendah. Begitu pula dengan kemampuan representasi siswa di sekolah sampai saat ini masih rendah. Hal ini dapat dilihat dari jawaban siswa dalam mengerjakan soal. Siswa kurang mampu menerjemahkan suatu permasalahan ke dalam model matematika atau sebaliknya. Penelitian ini bertujuan untuk mengetahui pengaruh penggunaan model pembelajaran Artikulasi dan Team Games Tournament (TGT) terhadap kemampuan representasi matematis siswa kelas X SMAK Baleriwu Danga pada pokok bahasan Sistem
\end{abstract}


Persamaan Linear Dua Variabel (SPLDV). Metode yang digunakan dalam peneltian ini adalah metode eksperimen. Pengambilan kelas dalam penelitian ini adalah "Randomized Posttest-Only Control Design" yaitu tiga kelompok yang masingmasing dipilih secara random kemudian diberikan tes akhir pada ketiga kelompok tersebut. Dimana kelas X IPA 1 dan IPA 2 sebagai kelas eksperimen dan kelas X IPS 1 sebagai kelas kontrol. Hasil penelitian yang dilakukan adalah persentasi nilai kemampuan representasi matematis siswa kelas Artikulasi sebesar 81,75\%, kelas TGT sebesar 66,09\% dan kelas kontrol sebesar 62,84\%.

Kata Kunci : Representasi Matematis, Artikulasi, TGT.

\section{PENDAHULUAN}

Permasalahan matematika sering muncul di kehidupan kita. Seiring dengan permasalahan yang terjadi, lembaga pendidikan memiliki peran dalam membantu siswa agar mampu hidup produktif di masyarakat dengan berbagai permasalahan yang dihadapi. Pendidikan selama ini berorientasi pada penguasaan mata pelajaran. Sehingga siswa tidak mengetahui manfaat materi yang dipelajari dalam kehidupan sehari-hari. Terlebih untuk mata pelajaran matematika.

Pembelajaran matematika bertujuan agar siswa mempunyai kemampuan untuk mengungkapkan ide-ide matematis untuk menyelesaikan masalah. Salah satu kemampuan matematika yang harus dimiliki siswa adalah kemampuan representasi. Alfani (2013) mengungkapkan bahwa kemampuan representasi mendorong siswa untuk memahami konsep matematika yang dipelajari, mengkomunikasikan ide-ide matematika, mengenal hubungan diantara konsep matematika dan menerapkan matematika untuk menyelesaikan permasalahan. Sehingga kemampuan representasi penting untuk memperkaya pengetahuan. Menurut Muthminnah (2014) "representation systems fulfil certain requirements for complexity interrelationship and power of symbolization and abstraction; mastering them broadens and enriches human intelligence, in that they are useful instruments for modeling reality and practical tolls for solving different problems in real life". Artinya, sistem representasi memenuhi persyaratan tertentu untuk komplesitas, keterkaitan dan kekuatan simbolisasi dan abstraksi; menguasai, memperluas dan memperkaya kecerdasan manusia, dalam arti bahwa mereka adalah instrumen yang berguna untuk pemodelan realitas dan alat-alat praktis untuk memecahkan masalah yang berbeda dalam 
kehidupan nyata. Oleh karena itu, kemampuan representasi dianggap sangat penting dalam keberhasilan pembelajaran matematika.

Berkaitan dengan hal tersebut, dalam pembelajaran matematika dibutuhkan model pembelajaran yang dapat mempengaruhi kemampuan representasi matematis siswa. Adanya model pembelajaran yang sesuai, dapat membantu kemampuan representasi siswa dalam mempelajari pelajaran matematika. Model pembelajaran yang dipakai pada penelitian ini adalah model pembelajaran kooperatif Team Games Tournament (TGT) dan Artikulasi. Kedua model ini lebih cocok dalam mempengaruhi kemampuan representasi matematis siswa dalam pelajaran matematika. Siswa menjadi lebih percaya diri dalam menjawab semua pertanyaan yang diberikan guru, dan mampu menjelaskan kepada teman sekelasnya. Kemampuan representasi matematis siswa dalam pembelajaran kooperatif sangat dibutuhkan oleh guru, sehingga tidak hanya guru yang selalu berperan aktif dalam proses belajar mengajar. Kedua model ini memiliki persamaan yakni siswa dibentuk dalam beberapa kelompok kecil. Dalam model artikulasi lebih diutamakan pada keaktifan siswa dalam mengembangkan kemampuan representasi matematisnya. Setelah pemberian materi, siswa dibentuk dalam beberapa kelompok kecil dan menjelaskan kembali pelajaran yang di berikan dengan menceritakan kembali apa yang telah dipahami kepada teman sekelompoknya lalu menjelaskan kepada teman sekelasnya. Sedangkan dalam model TGT, lebih diarahkan pada game yang telah disediakan oleh guru dimana siswa dibagi dalam beberapa kelompok. Saat kerja kelompok, guru membagikan LKS. Untuk memastikan bahwa seluruh anggota kelompok telah menguasai pelajaran, semua siswa sekelas diberikan permainan akademik. Siswa akan dibagi dalam meja-meja turnamen. Setiap meja permainan, diusahakan agar tidak ada peserta dari kelompok yang sama (Suprijono, 2001).

Penelitian terdahulu yang pernah dilakukan diantaranya sebagai berikut. Penelitian Rindiantika (2017) mengenai penerapan pembelajaran tipe artikulasi untuk meningkatkan aktivitas, motivasi, dan hasil belajar siswa; Wepe (2016) meneliti tentang pengaruh model pembelajaran kooperatif tipe artikulasi dengan peta konsep terhadap motivasi dan hasil belajar siswa; Purnamasari (2014) mengenai pengaruh pembelajaran TGT terhadap kemandirian belajar dan peningkatan kemampuan penalaran dan koneksi matematik siswa; Rahmawati (2017)tentang implementasi 
teams games tournaments dan number head together ditinjau dari kemampuan penalaran matematis. Berdasarkan penelitian-penelitian terdahulu tersebut, belum ada yang membahas tentang pengaruh model pembelajaran tipe artikulasi dan Team Games Tournament (TGT) terhadap kemampuan representasi matematis.

\section{METODE PENELITIAN}

Jenis penelitian pada penelitian ini adalah Quasi Eksperimen (Eksperimen Semu) dimana peneliti menerima apa adanya kelompok atau kelas yang sudah ada sehingga tidak memungkinkan untuk menempatkan subyek secara random ke dalam kelompok- kelompoknya. Menurut Sugiyono (2011:77) eksperimen semu adalah penelitian yang mempunyai kelompok kontrol, tetapi tidak berfungsi sepenuhnya untuk mengontrol variabel-variabel luar yang mempengaruhi pelaksanaan eksperimen. Reliabilitas bertujuan untuk mengetahui pengukuran yang konsisten, apabila dilakukan pengukuran dua kali atau lebih terhadap gejala yang sama dengan alat pengukur yang sama (Syofian Siregar: 87). Penelitian ini dilaksanakan di SMAK Baleriwu Danga.

\section{HASIL DAN PEMBAHASAN}

Peneliti mengajarkan materi Sistem Persamaan Linear Dua Variabel (SPLDV) menggunakan model pembelajaran Artikulasi dan Team Games Tournament (TGT) pada kelas eksperimen. Sedangkan model pembelajaran konvensional pada kelas kontrol. Data yang digunakan dalam penelitian ini adalah hasil test kemampuan representasi matematis siswa (posttest). Berdasarkan tes kemampuan representasi matematis yang telah diberikan, diperoleh hasil kemampuan representasi matematis siswa dari kelas eksperimen dan kelas kontrol. Kemudian dilakukan perhitungan uji prasyarat analisis dan uji hipotesis.

Hasil tes kemampuan representasi matematis siswa pada kelas eksperimen menunjukkan bahwa siswa memiliki kemampuan representasi matematis yang bervariasi. Beberapa siswa menonjol pada satu indikator visual tetapi kurang pada indikator simbolik dan verbal. Ada yang menonjol pada visual dan simbolik, namun kurang pada verbal. Adapula yang dapat melakukan semua jenis representasi matematis. Umumnya yang dapat mencapai ketiga indikator ini adalah siswa yang 
berprestasi di kelas. Sesuai dengan perolehan data yang telah dianalisis didapatkan nilai $t$ untuk ketiga kelas yaitu:

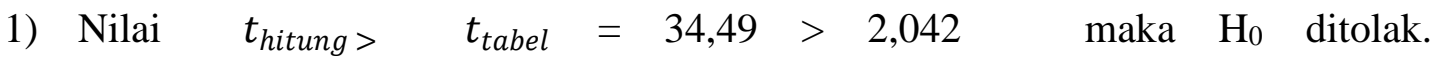
Kesimpulannya terdapat perbedaan pengaruh model pembelajaran artikulasi dengan model pembelajaran konvensional terhadap kemampuan representasi matematis siswa kelas X SMAK Baleriwu Danga pada pokok bahasan Sistem Persamaan Linear Dua Varibel (SPLDV). Dengan demikian pembelajaran dengan model Artikulasi lebih baik daripada model konvensional.

2) Nilai $t_{\text {hitung }}>t_{\text {tabel }}=20,69>1,68$ maka $\mathrm{H}_{0}$ ditolak.

Kesimpulannya terdapat perbedaan pengaruh model pembelajaran TGT dengan model pembelajaran konvensional terhadap kemampuan representasi matematis siswa kelas X SMAK Baleriwu Danga pada pokok bahasan Sistem Persamaan Linear Dua Varibel (SPLDV). Dengan demikian pembelajaran dengan model TGT lebih baik daripada model konvensional.

3) Nilai $t_{\text {hitung }>} t_{\text {tabel }}=34,49>2,042$ maka $\mathrm{H}_{0}$ ditolak.

Kesimpulannya terdapat perbedaan pengaruh model pembelajaran. Artikulasi dengan model pembelajaran TGT terhadap kemampuan representasi matematis siswa kelas X SMAK Baleriwu Danga pada pokok bahasan Sistem Persamaan Linear Dua Varibel (SPLDV). Dengan demikian pembelajaran dengan model Artikulasi lebih baik daripada model TGT.

\section{KESIMPULAN DAN SARAN}

Berdasarkan penelitian yang dilaksanakan mengenai pembelajaran matematika dengan menggunakan model pembelajaran artikulasi dan TGT terhadap kemampuan representasi matematis siswa di SMAK Baleriwu Danga, dikesimpulkan sebagai berikut.

1. Pada semua indikator, kemampuan representasi matematis dengan model pembelajaran artikulasi berada pada kategori sangat tinggi.

2. Berdasarkan hasil uji hipotesis diketahui:

a. Pembelajaran dengan model Artikulasi lebih baik daripada model konvensional. 
b. Pembelajaran dengan model TGT lebih baik daripada model konvensional.

c. Pembelajaran dengan model Artikulasi lebih baik daripada model TGT.

Beberapa saran yang dapat disampikan diantarnya sebagai berikut.

1. Model Pembelajaran Artikulasi dapat dijadikan sebagai salah satu cara belajar baru bagi siswa untuk meningkatkan hasil belajarnya.

2. Bagi guru, sebagai masukan untuk memperoleh gambaran mengenai penerapan model pembelajaran artikulasi dalam upaya meningkatkan kemampuan representasi matematis siswa, sehingga dapat dijadikan alternatif dalam pembelajaran matematika di kelas.

\section{REFERENSI}

Alfani, Amelian. 2013. Peningkatan Kemampuan Representasi Matematis Siswa SMP melalui Penerapan Pendekatan Metakognitif. Skripsi. Bandung: FMIPA Universitas Pendidikan Indonesia.

Muthminnah. 2014. Meningkatkan Kemampuan Representasi Matematis Melalui Pendekatan Pembelajaran Metaphorical Thinking. Skripsi. PDF: Universitas Islam Syarif Hidayatullah.

Purnamasari, Yanti. 2014. Pengaruh Model Pembelajaran Kooperatif Tipe Teams Games Tournament (TGT) terhadap Kemandirian belajar dan Peningkatan Kemampuan Penalaran dan Koneksi Matematik Peserta Didik SMPN 1 Kota Tasikmalaya. Jurnal Pendidikan dan Keguruan, 1(1).

Rahmawati, Nurina Kurniasari. 2017. Implementasi Teams Games Tournaments dan Number Head Together Ditinjau dari Kemampuan Penalaran Matematis. Al Jabar: Jurnal Pendidikan Matematika, 8(2), 121-134.

Rindiantika, Erva Septi. 2017. Penerapan Model Pembelajaran Kooperatif Tipe Artikulasi untuk Meningkatkan Aktivitas, Motivasi, dan Hasil Belajar Geografi di SMAN 1 Natar Tahun 2015/2016. Skripsi. Universitas Lampung.

Siregar, Syofian. 2012. Statistik Parametrik untuk Penelitian Kuantitatif. Jakarta: PT.Bumi Aksara.

Sugiyono. 2015. Metode Penelitian Pendidikan. Bandung: Afabeta.

Suprijono, Agus. 2001. Model- model Pembelajaran. Jakarta: Gramedia Pustaka Jaya. 
Wepe, Sakalus; Suratno; Bevo Wahono. 2016. Pengaruh Model Pembelajaran Kooperatif Tipe Artikulasi dengan Peta Konsep terhadap Motivasi dan Hasil Belajar IPA Biologi Siswa. Jurnal Edukasi UNEJ, 3(2), 13-18. 